J. Dairy Sci. 92:621-625

doi:10.3168/jds.2008-1526

(c) American Dairy Science Association, 2009.

\title{
Short communication: Haptoglobin as an early indicator of metritis
}

\author{
J. M. Huzzey, ${ }^{*}$ T. F. Duffield,† S. J. LeBlanc,† D. M. Veira,‡ D. M. Weary, ${ }^{\star}$ and M. A. G. von Keyserlingk ${ }^{\star 1}$ \\ ${ }^{*}$ Animal Welfare Program, Faculty of Land and Food Systems, University of British Columbia, 2357 Main Mall, Vancouver, British Columbia, \\ V6T 1Z4, Canada \\ †Department of Population Medicine, Ontario Veterinary College, University of Guelph, Ontario, N1G 2W1, Canada \\ $\ddagger$ Agriculture and Agri-Food Canada, PO Box 1000, Agassiz, British Columbia, V0M 1A0, Canada
}

\section{ABSTRACT}

The purpose of this study was to determine whether haptoglobin $(\mathrm{Hp})$ could be used as a predictive measure for metritis. Cattle were grouped into 3 health categories based on the condition of vaginal discharge and body temperature after calving: severe metritis (n $=12)$, mild metritis $(\mathrm{n}=32)$, and healthy $(\mathrm{n}=23)$. Blood was collected and analyzed for Hp concentration on $\mathrm{d}-20 \pm 5,-6 \pm 2,-2 \pm 1$, and $\mathrm{d} 0$ relative to calving, and then every $3 \mathrm{~d}$ after calving until $\mathrm{d}+21$. Cows with mild and severe metritis had greater Hp concentrations than healthy cows between $\mathrm{d} 0$ and $\mathrm{d}+12$. Mean $( \pm \mathrm{SE})$ Hp concentrations peaked on $\mathrm{d}+3$ in the cows with mild metritis $(1.06 \pm 0.15 \mathrm{~g} / \mathrm{L})$ and on $\mathrm{d}+6$ in cows with severe metritis $(1.62 \pm 0.47 \mathrm{~g} / \mathrm{L})$. Mean concentrations for the healthy group were $0.58 \pm 0.12$ $\mathrm{g} / \mathrm{L}$ and $0.31 \pm 0.08 \mathrm{~g} / \mathrm{L}$ on $\mathrm{d}+3$ and $\mathrm{d}+6$, respectively. Clinical signs of pathological discharge for the mildly and severely metritic cows did not occur until, on average, $8.6 \pm 3.9 \mathrm{~d}$ and $5.3 \pm 1.9 \mathrm{~d}$ after calving, respectively. Cows with $\mathrm{Hp}$ concentrations $\geq 1 \mathrm{~g} / \mathrm{L}$ on $\mathrm{d}$ +3 were 6.7 times more likely to develop severe or mild metritis; this predictive threshold has a sensitivity of $50 \%$ and specificity of $87 \%$. These results indicate that an acute phase inflammatory response precedes clinical metritis and that Hp screening may assist in the early detection of metritis, providing increased opportunities for early treatment and prevention.

Key words: transition cow, haptoglobin, metritis

Metritis, also known as early metritis or puerperal metritis, is a uterine infection characterized by fetid discharge and systemic signs of illness (fever, dullness, anorexia) occurring within the first few weeks after calving (Sheldon et al., 2006). This disorder occurs frequently and is known to impair reproductive performance (Opsomer et al., 2000; Melendez et al., 2004) and reduce milk yield regardless of the severity of

Received July 4, 2008.

Accepted October 3, 2008.

${ }^{1}$ Corresponding author: nina@interchange.ubc.ca the infection (Rajala and Gröhn, 1998; Huzzey et al., 2007). Improved detection of cows at risk for metritis would assist early treatment and the development of management strategies aimed at prevention.

Many studies in both cattle and sheep have reported an association between circulating concentrations of haptoglobin (Hp), an acute phase protein, and uterine infection after calving (Skinner et al., 1991; Smith et al., 1998a; Regassa and Noakes, 1999; Sheldon et al., 2001). For example, Regassa and Noakes (1999) found a greater $\mathrm{Hp}$ concentration in postpartum ewes with uterine bacterial contamination than in comparable ewes with normal uterine involution. Williams et al. (2007) showed that bacterial contamination of the uterine lumen in cattle was associated with an increase in Hp concentration. Haptoglobin binds to hemoglobin and so inhibits bacterial proliferation by reducing the availability of iron. Although there are many different acute phase proteins, the measurement of Hp has been of particular interest for detecting inflammation in cattle due to its virtual absence in the serum of healthy animals (Eckersall and Conner, 1988; Eckersall, 2000). Moreover, $\mathrm{Hp}$ is more commonly available as a routine analyte in veterinary diagnostic laboratories (Eckersall, 2000) and has the potential to be measured using semiautomatic assays or robotic systems (Smith et al., 1998b).

Previous work has shown an association between elevated $\mathrm{Hp}$ and clinical metritis in cows (Hirvonen et al., 1999; Humblet et al., 2006) but it is not clear whether these changes precede or are a consequence of uterine infection. The objectives of this study were to 1) describe how $\mathrm{Hp}$ levels vary in relation to the onset of clinical metritis, and 2) determine if Hp levels can be used to identifying cows at risk for metritis.

A total of 32 primiparous and 69 multiparous (parity of the calving event that occurred during the study = $3.2 \pm 1.3$; mean $\pm \mathrm{SD}$ ) Holstein dairy cows were monitored. These are the same cows described in Huzzey et al. (2007), but the present study reports additional data that were not available at the time of that report. All animals were cared for according to the guidelines established by the Canadian Council on Animal Care 
(1993). Cows were housed in pre- and postpartum group pens, each maintained at 20 cows. The experimental pens provided 20 free-stalls, 12 electronic feeding stations, and 2 electronic water stations [Insentec, Marknesse, Holland; see Chapinal et al. (2007) for a description and validation of this system]. Cows entered the prepartum pen $25 \pm 2 \mathrm{~d}$ before their expected calving date and were moved to the maternity pen when they showed signs of imminent calving (i.e., udder enlargement, milk letdown, relaxation of tail ligament). The maternity pen consisted of a sand-bedded pack with 6 Insentec feeders and 1 Insentec water trough. Cows were moved to the postpartum pen within $24 \mathrm{~h}$ of calving and were monitored for an additional $21 \mathrm{~d}$. After calving, cows were milked twice daily at approximately 0700 and $1700 \mathrm{~h}$.

The electronic feeding system was used to continuously monitor individual feed intakes for all experimental cows. The average DMI during the week before calving was included as a covariate in the logistic model evaluating $\mathrm{Hp}$ as determinant of metritis risk, following Huzzey et al. (2007) who identified a decline in DMI from 2 wh prepartum as a significant predictor of metritis risk. Cows were fed twice daily at approximately 0800 and $1600 \mathrm{~h}$. Prepartum BCS (Wildman et al., 1982) was evaluated on $\mathrm{d}-20 \pm 2$ and $\mathrm{d}-10 \pm$ 2 (relative to expected calving date) and prepartum BW was measured over 3 consecutive days on $d-20 \pm$ 2 relative to the expected calving date. Calving ease was recorded as either assisted or unassisted. Retained placenta (RP) was diagnosed if, $24 \mathrm{~h}$ after calving, the placenta was observed hanging from the vulva. Cows with RP were treated with procaine penicillin $\mathrm{G}$ intramuscularly for 3 consecutive days as per standard operating procedures on the farm.

Blood serum was sampled on $\mathrm{d}-20 \pm 5,-6 \pm 2,-2$ $\pm 1,0,+3,+6,+9,+12,+15,+18$, and +21 , relative to each cow's actual calving date. Blood was collected from the coccygeal vein (Vacutainer, Becton Dickinson, Franklin Lakes, NJ) at approximately 0900 h. Blood was allowed to clot at room temperature for up to 3 $\mathrm{h}$ and then was centrifuged at $1,400 \times g$ for $10 \mathrm{~min}$. Serum was harvested and frozen at $-20^{\circ} \mathrm{C}$ for later analysis. Haptoglobin was measured using a Hitachi 911 Autoanalyzer (Roche Diagnostics, Hoffman-La Roche Ltd., Montreal, Quebec, Canada) at the University of Guelph Animal Health Laboratory (Ontario, Canada).

Vaginal discharge (VD) for each individual was assessed immediately following the morning milking $(0730$ to $0900 \mathrm{~h})$ every $3 \mathrm{~d}$ after calving until d +21 . The appearance and smell of the discharge was evaluated and assigned to category: no mucus or clear mucus $=0$; cloudy mucus or mucus with flecks of pus $=1$; mucopurulent ( $\leq 50 \%$ pus present) and foul smelling
$=2 ;$ purulent $(\geq 50 \%$ pus present $)$ and foul smelling $=3$; or putrid (red/brown color, watery, foul smelling) $=4$. Rectal temperature was taken daily after calving using a digital thermometer (GLA M525/550, GLA Agricultural Electronics, San Luis Obispo, CA). These following categorization of cows (severely and mildly metritic) is based on the definitions for puerperal (severe) and clinical (mild) metritis as defined by Sheldon et al. (2006). Cows were classified as having severe metritis if they had at least one VD score of 4 and one recorded fever $\left(\geq 39.5^{\circ} \mathrm{C}\right)$ within $\pm 1 \mathrm{~d}$ of the VD score of 4 . Cows were classified as having mild metritis if they had a VD score of 4 and no fever or at least one VD score of 2 or 3 and no VD score of 4 (these cows may or may not have had a fever). Healthy cows had a maximum VD score of 1 and no fever after calving. Cows that had clinical signs of other transition-related disorders within the first 21 DIM [i.e., mastitis (16), miscellaneous health problems (7) and cows with a VD $=0 / 1$ and an unexplained fever (11)] were not included in the study. Following the removal of cows that did not meet the classification criteria for the 3 health categories, 67 cows were included in the study: 12 with severe metritis ( 5 primiparous and 7 multiparous), 32 with mild metritis (13 primiparous and 19 multiparous), and 23 healthy cows ( 5 primiparous and 18 multiparous).

The PROC MIXED procedure in SAS (version 9.1; SAS Institute, 2003) was used to analyze differences in Hp and VD between the 3 health categories using cow $(\mathrm{n}=67)$ as the experimental unit. The models included the fixed effects of parity (primiparous or multiparous), day of sample relative to calving, health status (healthy, mild metritis, or severe metritis), and the day by health status interaction. Cow was treated as a random effect, day as the repeated measure, and a compound symmetry and autoregressive covariance structure was used for the Hp and VD models, respectively (Bayesian information criterion closest to zero). When a significant $(P<0.05)$ day $\times$ health status interaction was detected the dependent variable was stratified by day of sample relative to calving.

Logistic regression was used to analyze $\mathrm{Hp}$ as a potential determinant of postpartum metritis risk (both mild and severe metritis combined). Calving ease, BCS, and BW were analyzed in univariate logistic models to determine which covariates to offer to the final logistic model evaluating $\mathrm{Hp}$ as potential determinant of postpartum metritis risk. The presence or absence of an RP could not be included as a covariate as it destabilized the model because there were no RP in the healthy group of cows. Because RP may cause an increase in serum Hp concentration in the days following calving, we tested if this would be a confounding factor that influenced the association between $\mathrm{Hp}$ and metritis by 


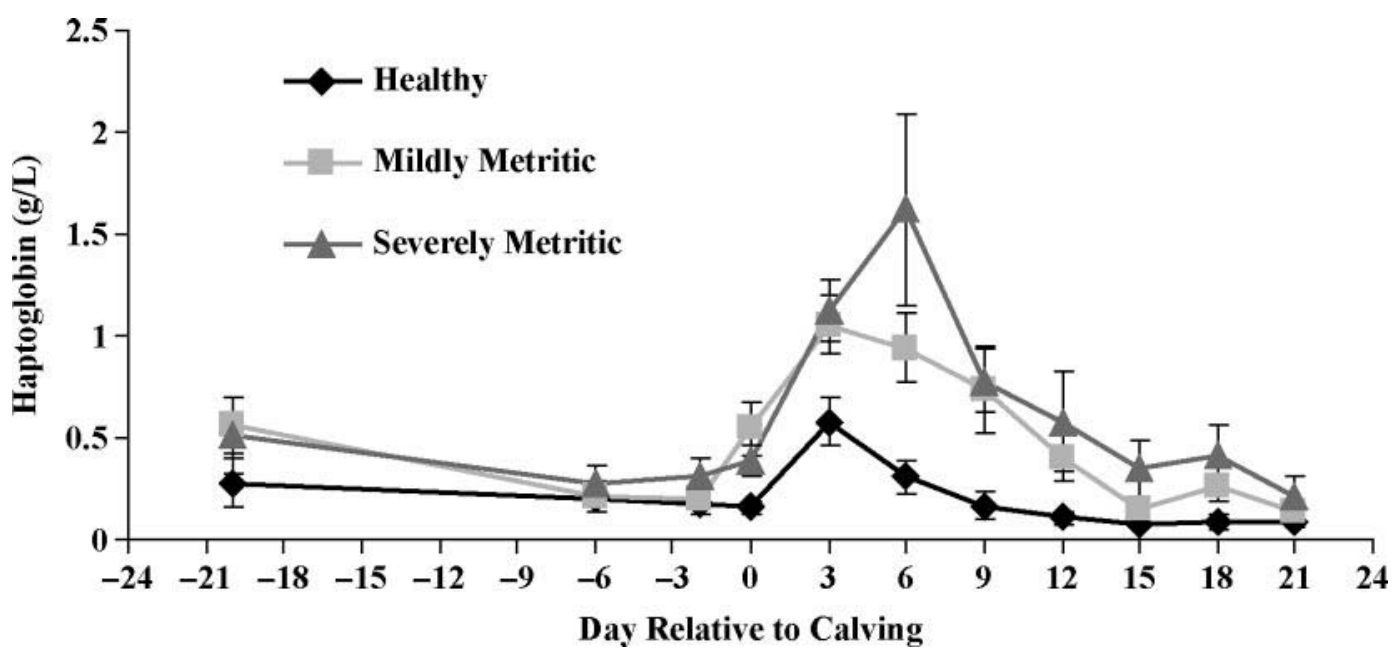

Figure 1. Mean $( \pm \mathrm{SE})$ haptoglobin concentration of healthy $(\mathrm{n}=23)$, mildly metritic $(\mathrm{n}=32)$, and severely metritic $(\mathrm{n}=12)$ cows during the period around calving.

assessing $\mathrm{Hp}$ in a separate logistic model with RP as the outcome variable.

A range of cut-points for $\mathrm{Hp}$ concentration for a range of days relative to calving were evaluated for association with subsequent metritis incidence. Only metritis cases that occurred after the Hp sample of interest were included in this analysis. For example, to determine if a $\mathrm{Hp}$ cut-point on $\mathrm{d}+3$ relative to calving was a predictor of metritis, the only cows used in this analysis were those that showed no signs of clinical metritis (mild or severe) from calving up to and including $d+3$. Sensitivity was the proportion of animals diagnosed with mild or severe metritis that were at or above a given cut-point, and specificity was the proportion of animals that did not have mild or severe metritis that were below a given cut-point. The odds ratio represents the ratio of the odds of a cow developing metritis at or above a set cut-point to the odds of a cow developing metritis below the set cut-point. For example, an odds ratio of 1 indicates that the chance of developing metritis is equally likely in groups below or above the given cut-point, and an odds ratio of 2 would indicate that cows at or above the set cut-point are 2 times more likely to develop metritis (severe or mild) than cows below the set cut-point. The likelihood ratio $[\mathbf{L R}=$ sensitivity $/(1-$ specificity $)]$ describes the probability of an animal, subsequently diagnosed with mild or severe metritis, having a test result at or above a given cut-point compared with a similar result in an unaffected animal.

There was a day by health status interaction for $\mathrm{Hp}$ $(P=0.001)$, and subsequent analysis revealed that cows with mild or severe metritis had greater Hp concentrations than healthy cows between $\mathrm{d} 0$ and $\mathrm{d}+12$ relative to calving (Figure 1; $P \leq 0.02$ ). In the present study, cows with normal uterine health after calving showed a spike in $\mathrm{Hp}$ concentration on $\mathrm{d}+3$ after calving followed by a gradual decline until $\mathrm{d}+12$ when $\mathrm{Hp}$ levels stabilized at approximately $0.1 \mathrm{~g} / \mathrm{L}$. These results are consistent with those of others (Uchida et al., 1993; Humblet et al., 2006; Drillich et al., 2007) showing that the period around calving is associated with an acute phase response that can be detected by a change in $\mathrm{Hp}$ concentration. Haptoglobin concentration peaked on d +3 in the mildly metritic cows $(1.06 \pm 0.15 \mathrm{~g} / \mathrm{L})$ and on $\mathrm{d}+6$ in the severely metritic cows $(1.62 \pm 0.47$ $\mathrm{g} / \mathrm{L})$. Haptoglobin concentration in healthy cows averaged $0.58 \pm 0.12$ and $0.31 \pm 0.08 \mathrm{~g} / \mathrm{L}$ on $\mathrm{d}+3$ and $\mathrm{d}$ +6 , respectively.

There was also a day by health status interaction for VD $(P<0.001)$, with the strongest differences between the groups occurring between $\mathrm{d}+6$ and $\mathrm{d}+18$ relative to calving (Figure 2). The first signs of abnormal VD $(\mathrm{VD} \geq 2)$ in the cows with mild and severe metritis occurred, on average, at $8.6 \pm 3.9 \mathrm{~d}$ and $5.3 \pm 1.9 \mathrm{~d}$ after calving, respectively.

The covariates in the final logistic model of $\mathrm{Hp}$ as a determinant of risk of metritis included calving difficulty $(P=0.03)$ and wk -1 DMI $(P=0.005)$. Prepartum BCS and BW were not associated with postpartum metritis outcome ( $P=0.8$ and 0.4 , respectively). After accounting for the variation associated with these covariates, for every unit increase $(1 \mathrm{~g} / \mathrm{L})$ in Hp concentration on $\mathrm{d}+3$ the risk of mild or severe metritis increased 3.12 times $\left[P_{\text {Wald }}=0.03 ; 95 \%\right.$ confidence interval $\left(\mathbf{C I}_{95}\right)=$ $1.1,8.9]$. This model accounted for $26 \%$ of the variation in metritis risk $\left(\mathrm{R}^{2}=0.26 ; P_{\text {Likelihood Ratio }}<0.001\right)$. Cows with an $\mathrm{Hp}$ concentration greater than or equal to $1 \mathrm{~g} / \mathrm{L}$ 


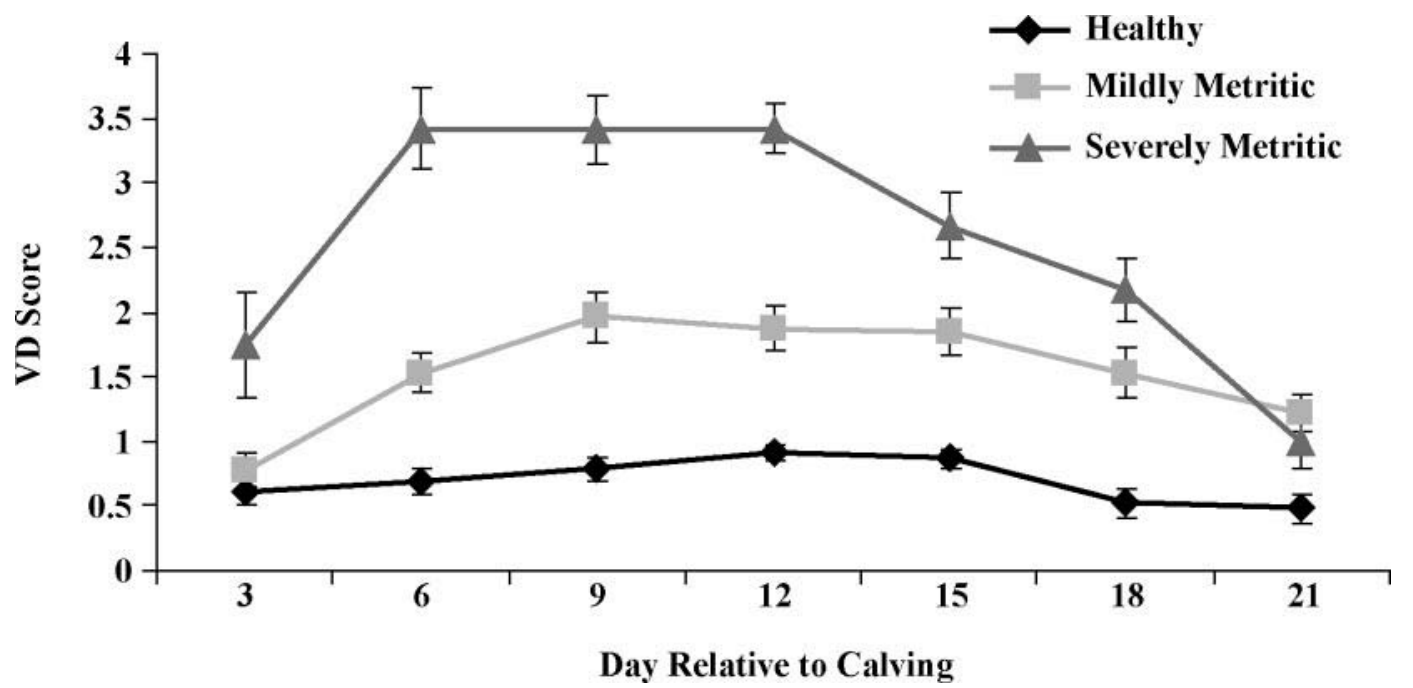

Figure 2. Change in vaginal discharge (VD) score (mean $\pm \mathrm{SE})$ over a 21-d period after calving for healthy $(\mathrm{n}=23)$, mildly metritic $(\mathrm{n}=$ $32)$, and severely metritic $(\mathrm{n}=12)$ cows.

on $\mathrm{d}+3$ were 6.7 times more likely to be subsequently diagnosed with mild or severe metritis (Table 1). This predictive measure resulted in a relatively high specificity $(87 \%)$ or low false positive rate $(13 \%)$; however, the sensitivity of this measure was low (50\%), meaning that this predictive threshold was only able to identify half of the cows with severe or mild metritis. This indicates that although there is a strong association between metritis and Hp levels $3 \mathrm{~d}$ after calving, there is still considerable variation not accounted for in our model.

In general, it is not feasible for commercial dairy herds to measure individual feed intake; therefore, we ran the logistic model described above without wk -1 DMI included as a covariate. This model accounted for $19 \%$ of the variation in metritis risk $\left(\mathrm{R}^{2}=0.19\right.$; $\left.P_{\text {Likelihood Ratio }}=0.001\right)$ and indicated that for every unit increase $(1 \mathrm{~g} / \mathrm{L})$ in Hp concentration on $\mathrm{d}+3$ the risk of mild or severe metritis increased 3.8 times $\left[P_{\text {Wald }}=\right.$ $\left.0.01 ; \mathrm{CI}_{95}=1.3,11.1\right]$.

Because $\mathrm{Hp}$ is a nonspecific indicator of inflammation, several factors can make relationships between this metabolite and metritis difficult to interpret. In this study the response was not associated with inflammation of the udder because cows with clinical mastitis were removed from the analysis. We tested to see if the elevated $\mathrm{Hp}$ levels immediately after calving were simply due to the presence or absence of a RP. There was a $58 \%$ incidence rate of $\mathrm{RP}$ in the severely metritic group, whereas only $9 \%$ of the mildly metritic cows had an RP. The Hp levels on $\mathrm{d} 0$ and $\mathrm{d}+3$ were not related to the presence or absence of RP after calving $(P=$ 0.4 ). Calving difficulty was included as a covariate in the logistic model evaluating the association between $\mathrm{d}+3 \mathrm{Hp}$ and metritis risk; therefore, the elevated $\mathrm{Hp}$

Table 1. Haptoglobin cut-points on $\mathrm{d}+3$ for identifying cows with subsequent metritis (severe or mild metritis) within the first $21 \mathrm{~d}$ of lactation

\begin{tabular}{|c|c|c|c|c|c|c|c|c|c|}
\hline Variable & $\begin{array}{l}\text { Cut- } \\
\text { point }\end{array}$ & $\begin{array}{c}\text { Cows } \\
\text { at/above } \\
\text { cut-point, } \\
\%\end{array}$ & $\begin{array}{c}\text { Cows at/above } \\
\text { cut-point that } \\
\text { subsequently } \\
\text { developed } \\
\text { metritis, \% }\end{array}$ & $\begin{array}{c}\text { Cows below cut- } \\
\text { point that } \\
\text { subsequently } \\
\text { developed } \\
\text { metritis, } \%\end{array}$ & $\begin{array}{l}\text { Odds } \\
\text { ratio }^{1}\end{array}$ & $\begin{array}{c}\text { Sensitivity, } \\
\%\end{array}$ & $\begin{array}{c}\text { Specificity, } \\
\%\end{array}$ & $\begin{array}{l}\text { Likelihood } \\
\text { ratio }\end{array}$ & $P$-value \\
\hline \multirow{6}{*}{$\begin{array}{l}\text { Serum haptoglobin } \\
\text { on } \mathrm{d}+3 \\
(\mathrm{~g} / \mathrm{L}) ; \mathrm{n}=59\end{array}$} & $\geq 0.2$ & 86.4 & 66.7 & 25.0 & 6.0 & 94.4 & 26.1 & 1.3 & 0.05 \\
\hline & $\geq 0.4$ & 72.9 & 69.8 & 37.5 & 3.8 & 83.3 & 43.5 & 1.5 & 0.02 \\
\hline & $\geq 0.6$ & 52.5 & 77.4 & 42.9 & 4.6 & 66.7 & 69.6 & 2.2 & 0.007 \\
\hline & $>1.2$ & 28.8 & 82.4 & 52.4 & 4.2 & 38.9 & 87.0 & 3.0 & 0.03 \\
\hline & $\geq 1.4$ & 23.7 & 85.7 & 53.3 & 5.3 & 33.3 & 91.3 & 3.8 & 0.03 \\
\hline & $>1.6$ & 16.9 & 80.0 & 57.1 & 3.0 & 22.2 & 91.3 & 2.6 & 0.18 \\
\hline
\end{tabular}

${ }^{1}$ Odds ratio calculated from $2 \times 2$ contingency table generated for each cut-point. 
concentrations on that day were not simply an effect of dystocia. This study utilized a relatively small sample size, and we therefore strongly encourage future work to evaluate the usefulness of $\mathrm{Hp}$ as a predictive measure on large commercial herds.

Although an Hp cutoff of $1 \mathrm{~g} / \mathrm{L}$ had the greatest combined sensitivity and specificity, potential field application of these results should consider the type of proposed intervention. For example, if antibiotic treatment for all positive tests was the intervention of choice, then a cut-point with the greatest specificity might be more appropriate; based on the results of this study that cut-point would be an $\mathrm{Hp}$ level $\geq 1.4 \mathrm{~g} / \mathrm{L}$ (specificity $=91.3 \%)$. Treatment based on a test with high specificity would minimize the number of cows being treated unnecessarily and would also minimize milk lost due to withdrawal periods. If, however, the intervention of choice involved increased monitoring of "high-risk" animals so that prompt treatment could occur when necessary, then a greater sensitivity may be preferred. For example, based on the results of this study an Hp cut-point of $\geq 0.4 \mathrm{~g} / \mathrm{L}$ ( might identify a subset of animals that warrant daily monitoring of rectal body temperatures to detect the first signs of illness.

Early detection of disease is critical for improving health management programs on dairy herds. This study provides evidence that there is an inflammatory response that precedes clinical signs of metritis and that this response can be detected by evaluating serum Hp concentration.

\section{ACKNOWLEDGMENTS}

The authors gratefully acknowledge the staff of the University of British Columbia's Dairy Education and Research Center and the University of Guelph's Animal Health Laboratory. In particular, we thank Katy Proudfoot, Erin Vernooy, and Amy Stanton for their efforts in data collection and managing the serum analysis. The UBC Animal Welfare Program is funded by the Natural Sciences and Engineering Research Council of Canada, Dairy Farmers of Canada, and many others listed at http://www.landfood.ubc.ca/animalwelfare.

\section{REFERENCES}

Canadian Council on Animal Care. 1993. Guide to the Care and Use of Experimental Animals. Vol. 1. E. D. Olfert, B. M. Cross, and A. A. McWilliam, ed. CCAC, Ottawa, Ontario, Canada.
Chapinal, N., D. M. Veira, D. M. Weary, and M. A. G. von Keyserlingk. 2007. Technical note: Validation of a system for monitoring individual feeding and drinking behavior and intake in grouphoused cattle. J. Dairy Sci. 90:5732-5736.

Drillich, M., D. Voigt, D. Forderung, and W. Heuwiesser. 2007. Treatment of acute puerperal metritis with flunixin meglumine in addition to antibiotic treatment. J. Dairy Sci. 90:3758-3763.

Eckersall, P. D. 2000. Recent advances and future prospects for the use of acute phase proteins as markers of disease in animals. Rev. Med. Vet. 151:577-584.

Eckersall, P. D., and J. G. Conner. 1988. Bovine and canine acute phase proteins. Vet. Res. Commun. 12:169-178.

Hirvonen, J., G. Huszenicza, M. Kulcsàr, and S. Pyörälä. 1999. Acutephase response in dairy cows with acute postpartum metritis. Theriogenology 52:1071-1083.

Humblet, M. F., H. Guyot, B. Boudry, F. Mbayahi, C. Hanzen, F. Rollin, and J. M. Godeau. 2006. Relationship between haptoglobin, serum amyloid A, and clinical status in a survey of dairy herds during a 6-month period. Vet. Clin. Pathol. 35:188-193.

Huzzey, J. M., D. M. Veira, D. M. Weary, and M. A. G. von Keyserlingk. 2007. Prepartum behavior and dry matter intake identify cows at risk for metritis. J. Dairy Sci. 90:3220-3233.

Melendez, P., J. McHale, J. Bartolome, L. F. Archbald, and G. A. Donovan. 2004. Uterine involution and fertility of Holstein cows subsequent to early postpartum $\mathrm{PGF}_{2 \alpha}$ treatment for acute puerperal metritis. J. Dairy Sci. 87:3238-3246.

Opsomer, G., Y. T. Gröhn, J. Hertl, M. Coryn, H. Deluyker, and A. de Kruif. 2000. Risk factors for postpartum ovarian dysfunction in high producing dairy cows in Belgium: A field study. Theriogenology $53: 841-857$.

Rajala, P. J., and Y. T. Gröhn. 1998. Effects of dystocia, retained placenta, and metritis on milk yield in dairy cows. J. Dairy Sci. 81:3172-3181.

Regassa, F., and D. E. Noakes. 1999. Acute phase protein response of ewes and the release of PGFM in relation to uterine involution and the presence of intrauterine bacteria. Vet. Rec. 144:502-506.

SAS Institute. 2003. Version 9.1 SAS User's Guide. SAS Institute Inc., Cary, NC.

Sheldon, I. M., G. S. Lewis, S. LeBlanc, and R. O. Gilbert. 2006 Defining postpartum uterine disease in cattle. Theriogenology 65:1516-1530.

Sheldon, I. M., D. E. Noakes, A. Rycroft, and H. Dobson. 2001. Acute phase protein responses to uterine bacterial contamination in cattle after calving. Vet. Rec. 148:172-175.

Skinner, J. G., R. A. Li. Brown, and L. Roberts. 1991. Bovine haptoglobin response in clinically defined field conditions. Vet. Rec. 128:147-149.

Smith, B. I., G. A. Donovan, C. A. Risco, C. R. Young, and L. H. Stanker. 1998a. Serum haptoglobin concentrations in Holstein dairy cattle with toxic puerperal metritis. Vet. Rec. 142:83-85.

Smith, J. E., P. S. Chavey, and G. A. Andrews. 1998b. Semiautomatic and robotic methods for determining serum haptoglobin levels. Vet. Clin. Pathol. 27:11-14.

Uchida, E., N. Katoh, and K. Takahashi. 1993. Appearance of haptoglobin in serum from cows at parturition. J. Vet. Med. Sci. 55:893-894.

Wildman, E. E., G. M. Jones, P. E. Wagner, R. L. Boman, H. F. Troutt, and T. N. Lesch. 1982. A dairy cow body condition scoring system and its relationship to selected production characteristics. J. Dairy Sci. 65:495-501.

Williams, E. J., D. P. Fischer, D. E. Noakes, G. C. W. England, A Rycroft, H. Dobson, and I. M. Sheldon. 2007. The relationship between uterine pathogen growth density and ovarian function in the postpartum dairy cow. Theriogenology 68:549-559. 